HTTP://DX.DOI.ORG/10.12775/SZHF.2016.043

\author{
FRYDERYK KWIATKOWSKI \\ Uniwersytet Jagielloński, KRaków, Polska \\ FRYDERYKKWIATKOWSKI@WP.PL
}

\title{
Problem wpływu teozofii Jakuba Böhmego na idealistyczny system Georga Wilhelma Fryderyka Hegla
}

Wśród historyków filozofii, a przede wszystkim samych heglistów, zagadnienie recepcji mistycznej twórczości Jakuba Böhmego ${ }^{1}$ w licznych dziełach

\footnotetext{
${ }^{1}$ Jakub Böhme (1575-1624) - urodził się we wsi Stary Zawidów. Początkowo wypasał bydło, jednak będąc wątłej budowy, nie mógł pracować na roli, dlatego posłano go, aby uczył się szewskiego rzemiosła. Pod wpływem mistycznego widzenia, którego doświadczył w 1600 r., mając do pomocy jedynie Pismo Święte, napisał dzieło Aurora, czyli jutrzenka o poranku (1612). Następnie uzyskał wsparcie finansowe osób zainteresowanych jego pracami, dzięki czemu mógł poświęcać swój czas na lekturę tekstów filozoficznych, alchemicznych i ezoterycznych. W związku z tym jego dzieła stopniowo zaczęły zyskiwać na klarowności przekazu. Więcej o życiu Böhmego, zob. J. Böhme, Sześć punktów teozoficznych, przeł. Ś. F. Nowicki, PWN, Warszawa 2013, s. XIII-XXVI.
} 
Hegla budzi wiele emocji $i^{2}$ Teozofia ${ }^{3}$ szewca $z$ Łużyc przez wiele lat spotykała się raczej z chłodnym, a nawet i nieżyczliwym nastawieniem ze strony badaczy. Wydaje się jednak, że była istotnym źródłem inspiracji dla Hegla, a z pewnością stanowi istotny klucz interpretacyjny do wyjaśnienia wielu aspektów jego filozofii. Historycy często dystansują się od poglądu głoszącego, że twórca filozofii ducha mógł być zaintrygowany myślą mistyka z Łużyc, $\mathrm{w}$ dodatku piszącego językiem wybitnie niezrozumiałym. W ostatnich dekadach można jednak zaobserwować wzrost zainteresowania kwestią ustalenia faktycznego „wpływu” pism Böhmego na myśl Hegla ${ }^{4}$. Powyższe zagadnienie wiąże się jednak $\mathrm{z}$ wieloma problemami o charakterze metodologicznym. Po pierwsze, precyzyjne ustalenie, $\mathrm{w}$ jakim zakresie myśl Böhmego znalazła swoje odbicie u Hegla utrudnia mętny styl, którym obaj myśliciele posługiwali się w objaśnianiu swoich koncepcji. W przypadku rekonstrukcji koncepcji Böhmego dodatkowych trudności nastręcza brak filozoficznej ogłady, jaką XVII-wieczny myśliciel dopiero nabywał w trakcie swojego intelektualnego rozwoju. Po drugie, sprawę utrudnia fakt, że choć z biegiem czasu Hegel wy-

${ }^{2}$ Do tej pory ukazało się kilka interesujących pozycji podejmujących to zagadnienie: E. Haldane, Böhme and His Relation to Hegel, „Philosophical Review” 1897, nr 2, s. 146-161; I. Schussler, Boehme und Hegel, "Jahrbuch der Schleischen Friedrich Wilhelms Universität" 1965, nr 10, s. 45-58; D. Walsh, The Esoteric Origins of Modern Ideological Thought: Boehme and Hegel (dysertacja doktorska) 1978, University of Virginia; tenże, The Historical Dialectic of Spirit: Jacob Boehme's Influence on Hegel, [w:] History and System: Hegel's Philosophy of History, red. R. L. Perkins, Albany, New York 1984, s. 15-46; K. Atala, A Study of the Nature of Reality and Language in J. Boehme's Aurora and G. W. F. Hegel's „Vorlesungen ueber die Philosophie der Religion III" (dysertacja doktorska), Catholic University of America 1988; S. McGrath, Boehme, Hegel, Schelling, and the Hermetic Theology of Evil, „Philosophy \& Theology"2006, s. 257-286; G. A. Magee, Hegel's Reception of Jacob Boehme, [w:] An Introduction to Jacob Boehme. Four Centuries of Thought and Reception, red. A. Hessayon, S. Apetrei, New York 2014, s. 224-243.

${ }^{3}$ Böhme uważany jest przede wszystkim za ojca i najważniejszego przedstawiciela nowożytnej teozofii. Jednym z jej wyznaczników jest prymat myślenia mitologicznego. Opiera się ono na hermeneutycznej interpretacji kanonicznych tekstów religijnych (najczęściej Biblii), w której wyeksponowane zostają elementy mityczne, jak na przykład rola Sofii i aniołów, upadek Lucyfera, wizja Ezechiela i inne. Więcej o chrześcijańskiej teozofii, jej wyznacznikach i historii rozwoju zob. A. Faivre, Christian Theosophy, [w:] Dictionary of Gnosis \& Western Esotericism, red. W. Hanegraaff, Brill, Leiden 2006, s. 258-267.

${ }^{4}$ Jedną z przyczyn tego trendu jest fakt dynamicznej instytucjonalizacji badań nad zachodnim ezoteryzmem. Do jej owoców można zaliczyć coraz bardziej precyzyjne ustalanie związków między twórczością reprezentantów tej tradycji myślowej, do której w pewnym zakresie zalicza się m.in. Böhmego, a filozofią europejską głównego nurtu. 
powiadał się o szewcu z Łużyc z coraz większą aprobatą, to jego stosunek do niemieckiego mistyka pozostał niejednoznaczny.

\section{Recepcja pism Böhmego we wczesnej twórczości Hegla}

W swych Wykładach $z$ historii filozofii (1833-183655) Hegel, pisząc o Böhmem, stwierdza, że „Z całą pewnością nie zasługuje on na pogardę, ale też $\mathrm{z}$ drugiej strony jest wiele przesady $\mathrm{w}$ tym wynoszeniu pod niebiosa, jakie miało [później] stać się jego udziałem"6. Język, jakiego używa ów mistyk, „uwięziony jest w wielkim twardym dębie tego co zmysłowe - w sękatym, twardym zroście wyobrażenia [...] Böhme jest pod względem myślowej kultury jeszcze tak daleko w tyle. Jedną stroną jest zupełnie prymitywne i barbarzyńskie przedstawienie, $\mathrm{z}$ drugiej strony poznaje się [u niego] niemiecki, głęboki umysł (Gemüt), który obcuje z tym, co najbardziej wewnętrzne, i ćwiczy w tym swą moc, swą siłę"7. To, co dla Hegla jest „barbarzyńskie” w teozoficzno-filozoficznej refleksji Böhmego, to przede wszystkim sposób jej przedstawienia. Mistyk posługuje się takimi określeniami, jak na przykład „siarka”, "gniew”, „męka”, w charakterze pojęć abstrakcyjnych. Ponadto nakłada na nie dyskurs religijny, ponieważ chce umieścić swoją teozofię w kontekście myśli chrześcijańskiej. Dla Hegla pisma Böhmego sytuują się w sferze religii ze względu na formę przekazu. Mistyk angażuje przede wszystkim myślenie obrazowe, które w filozofii Hegla wyrażają pojęcia Vorstellung i das vorstellende Denken. Böhme ucieka się do używania terminów przynależnych do różnych słowników - religijnego, przyrodniczego, alchemicznego czy emocjonalnego. Są one niesystematycznie wprowadzane, co też znacząco utrudnia zrozumienie jego zawiłej myśli ${ }^{8}$. „Nie musimy się go wstydzic"” - ponieważ to dzięki niemu narodziła się filozofia niemiecka i bez znajomości

\footnotetext{
${ }^{5}$ Prace wydane pośmiertnie.

${ }^{6}$ J. Böhme, dz. cyt., s. 218.

${ }^{7}$ G. W. F. Hegel, Wykłady z historii filozofii, t. 3, przeł. S. F. Nowicki, PWN, Warszawa 2013, s. $222,228$.
}

${ }^{8}$ Tamże, s. 227. Hegel, ostro piętnując styl Böhmego i niedociągnięcia metodologiczne w jego wywodzie, jest jednak nazbyt surowy w swej ocenie. Światosław Nowicki przekonuje, że słynny teozof dokształcał się, a jego styl stopniowo ewoluował, zyskując na jasności przedstawianej myśli. W późniejszym okresie Böhme coraz częściej czerpał z myśli kabalistycznej i tworzył własne pojęcia, odznaczające się wyższym poziomem abstrakcji niż zapożyczana terminologia alchemiczno-paracelsiańska obecna w jego dziełach $\mathrm{z}$ wczesnego okresu, zob. J. Böhme, dz. cyt., s. XXI-XXIII.

${ }^{9}$ G. W. F. Hegel, dz. cyt., s. 228. 
jego dzieł nie sposób jej zrozumiećn ${ }^{10}$. W swoich Wykładach $z$ historii filozofii Hegel obiera sobie za cel zrehabilitowanie twórczości Böhmego i przywrócenie mu należnego miejsca w tradycji niemieckiej filozofii. Oświecenie skazało na zapomnienie tego „pietystycznego marzyciela”, jednak romantycy na powrót odkryli jego głębię. Z teozofią Böhmego Hegel najprawdopodobniej zapoznał się w Jenie za pośrednictwem swego kolegi, Fryderyka Schellinga, ${ }^{11}$ między 1801 a 1807 rokiem. Na przełomie XVIII i XIX wieku Böhme cieszył się niemałą sławą $\mathrm{w}$ kręgach jenajskich romantyków. Schelling, posiadając opinię największego admiratora prac teozofa, z pewnością wywarł znaczny wpływ na Hegla, który w tamtym okresie był również jego uczniem. Tym samym nietrudno wyjaśnić, dlaczego w Wykładach $z$ historii filozofii Hegel poświęca osobny rozdział Jakubowi Böhme. Autor Fenomenologii ducha stawia łużyckiego teozofa obok Francisa Bacona, jako fundatora nowożytnej filozofii europejskiej. Podobnie jak w przypadku protestantyzmu naczelna zasada filozofii nowożytnej nakazuje zdaniem Hegla „umieścić świat intelektualny w głębi własnego umysłu (in das eigene Gemüt) i wszystko, co poprzednio było po tamtej stronie, oglądać, wiedzieć i czuć w swojej samowiedzy" ${ }^{12}$. Hegel przekonuje, że filozofia nowożytna opiera się na idei samoświadomości. Najjaskrawszym tego przykładem są oczywiście Medytacje Kartezjusza, który „odkrył” archimedesowy punkt filozofii w ludzkiej jaźni. Analiza samoświadomości stanowiła dla niego moment przełomowy w batalii ze sceptycyzmem, dla szewca z Łużyc zaś była źródłem jego teozoficznej refleksji. Böhme "ma wszystko w sobie samym, wie wszystko sam z siebie"13 $\mathrm{i}$, podążając za protestancką zasadą, pisze on „na podstawie własnej rzeczywistości, z głębi swego umysłu: to, co się dzieje w niebie, ma się u siebie - wokół siebie i w sobie”"14. Dla Hegla mistyczna myśl Böhmego, choć wyrażona w „prymitywny” i „barbarzyński” sposób, stanowi ważny punkt odniesienia, ponieważ dociera on do spekulatywnej prawdy. Należy pamiętać, że dla filozofa ze Stuttgartu

\footnotetext{
10 Tamże, s. 221.

${ }^{11}$ Z kolei Schelling zaczął swe studia nad Böhmem w 1799 r. dzięki znajomości z Ludwigiem Tieckiem. Istnieje jednak prawdopodobieństwo, że idee łużyckiego teozofa wywarły wpływ na Schellinga wcześniej. Ojciec Schellinga znalazł się w posiadaniu prac Fryderyka Krzysztofa Oetingera, które Schelling mógł czytać w młodym wieku. A jak powszechnie wiadomo, twórczość Böhmego wywarła olbrzymi wpływ na koncepcje Oetingera. Więcej na temat relacji między jenajskimi romantykami a Schellingiem, Heglem i Böhmem zob. G. A. Magee, dz. cyt., s. 225-227; P. Mayer, Jena Romanticism and Its Appropriation of Jacob Boehme, Montreal 1999.

${ }^{12}$ G. W. F. Hegel, dz. cyt., s. 222.

${ }^{13}$ Tamże, s. 259.

14 Tamże, s. 225.
} 
mistyka nie jest owocem irracjonalnych uniesień, lecz w ścisły sposób wiąże się z myśleniem dialektycznym:

Co się zaś tyczy znaczenia tego, co spekulatywne, to należy tu jeszcze wspomnieć, że trzeba przez to rozumieć to samo, co wcześniej, zwłaszcza w odniesieniu do świadomości religijnej i jej treści, zwykło się określać mianem tego, co mistyczne. Jeśli w dzisiejszych czasach mówi się o tym, co mistyczne, to z reguły jest to znaczeniowo równoważne $\mathrm{z}$ tym, co tajemnicze i niepojęte, a to tajemnicze i niepojęte jest następnie, w zależności od różnic co do ogólnej kultury, sposobu myślenia i wrażliwości, traktowane przez jednych jako coś właściwego i prawdziwego, przez innych zaś jako coś należącego do sfery zabobonu i ułudy [...] Wszystko to, co rozumowe ${ }^{15}$, można więc określić zarazem jako mistyczne, co jednak znaczy tylko tyle, że wykracza to poza rozsądek, ale w żadnym razie nie znaczy, że należy to traktować jako w ogóle niedostępne dla myślenia i niepojęte ${ }^{16}$.

Hegel wskazuje, że między mistyką i filozofią istnieje różnica w zakresie formy, ale nie treści. Przekonuje wręcz, że Böhme „zainteresowany najgłębiej ideą [...] chce wyłożyć spekulatywną prawdę"17. Autor Nauki logiki ma tutaj na myśli ideę absolutną, w której to, co obiektywne i subiektywne zostaje przezwyciężone. Idea pozostaje aktualna tylko w momencie, gdy odnosi się do siebie samej - w akcie samoodnoszącej się myśli, czyli w samoświadomości. Hegel, interpretując teozofię Böhmego, uważa, że ich wspólnym celem jest opisanie natury idei, która stanowi jedyny przedmiot i treść filozofii, sztuki i religii ${ }^{18}$. Tym, co pozwala Böhmemu na przezwyciężenie elementu obiektywnego i subiektywnego, jest używana przez niego metoda dialektyczna, która legnie również u podstaw systemu Hegla. Jak przekonuje Józef Piórczyński, to właśnie w niemieckim nurcie filozofii panteistyczno-mistycznej ukonstytuowała się nowożytna dialektyka ${ }^{19}$ - jej antycypację można

${ }^{15}$ Przez rozum (Vernunft), myślenie rozumowe, Hegel nazywał wnioskowanie filozoficzne, zaś rozsądek łączył z wnioskowaniem naukowym i potocznym.

${ }^{16}$ Dodatek do $\$ 82$ Encyklopedii nauk filozoficznych Hegla, cyt. za: Ś. F. Nowicki, Przedmowa, [w:] Sześć punktów teozoficznych, przeł. Ś. F. Nowicki, PWN, Warszawa 2013, s. XXXI-XXXII. ${ }^{17}$ G. W. F. Hegel, dz. cyt., s. 225; zob. G. W. F. Hegel, Vorlesungen über die Geschichte der Philosophie III, E. Moldenhauer, K. M. Michel, Frankfurt am Main 1986, s. 94: „Er steht im tiefsten Interesse der Idee, kämpft sich damit herum".

${ }^{18}$ G. W. F. Hegel, Nauka logiki, t. 2, przeł. A. Landman, Warszawa 2011, s. 677.

${ }^{19}$ J. Piórczyński, Absolut, człowiek, świat: studium myśli Jakuba Böhmego i jej źródeł, Warszawa 1991, s. $8-13$. 
dostrzec w twórczości Mistrza Eckharta, narodziny przeżywa w teozofii Böhmego, kulminację zaś w systemie Hegla ${ }^{20}$.

\section{Związki między dialektyką Böhmego i Hegla}

Terminowi „bezgrunt” (Ungrund) w teozofii Böhmego odpowiada heglowski byt. Bezgrunt to pojęcie pierwotne i w opozycji do der Grund, które można tłumaczyć jako „dno”, „podstawę”, „przyczynę”, „powód” Ungrund oznacza brak podstawy, uzasadnienia, uwarunkowania. Jest to głębia bez dna będąca nicością w sensie absolutnym (Nichts). Nie można w niej niczego wyróżnić ani określić, dlatego też jest wszystkim, gdyż nie ma niczego poza nią samą. Powyższe opisy budzą skojarzenia z pojęciem bytu w filozofii Hegla: „Byt jest czystą nieokreślonością i pustką [...] Jest prostą tożsamością (Gleichheit) ze sobą, całkowitą pustką i całkowitym brakiem określeń i treści - brakiem wszelkich odróżnień jako takich" ${ }^{21}$. Zmieniając kontekst, w jakim padły słynne słowa Hegla skierowane przeciwko filozofii Schellinga, można obrazowo stwierdzić, że bezgrunt to „noc, w której wszystkie krowy są czarne”. Ungrund, jako wieczne Nic, posiada jednak wolę, będącą niepohamowanym pragnieniem czegoś, dążeniem ku niewiadomo-czemu ${ }^{22}$. Bezgrunt, ponieważ nie ma niczego innego poza nim samym, z konieczności musi pożądać samego siebie. Zarówno w teozofii Böhmego, jak i w systemie Hegla, Bóg dąży do spełnienia na drodze samopoznania. Warunkiem możliwości wszelkiej wiedzy jest natomiast podział, wielość, rozszczepienie bytu, ponieważ, jak trafnie wskazuje Böhme: „w jednym jedynym bycie, w którym nie ma zróżnicowania, który jest tylko jednym - tam nie ma poznania"23. Dopiero gdy Bóg ujawnia się w czymś innym, przechodzi do wielości, zyskuje samowiedzę. Gdyby byt Böhmego był u swych podstaw statyczny, pozbawiony niepohamowanej woli, wtedy musiałby pozostać jednością pogrążoną w wiecznym

\footnotetext{
${ }^{20}$ Więcej o znaczeniu niemieckiej mistyki dla zrozumienia późniejszej tradycji dialektycznej, zob. tamże, s. 7-41.

${ }^{21}$ G. W. F. Hegel, Nauka logiki, t. 1, przeł. A. Landman, Warszawa 2011, s. 86.

${ }_{22}$ Tak rozumiany bezgrunt mógł lec u podstaw koncepcji ślepej woli Arthura Schopenhauera. W jego filozofii działalnie ślepej woli zostało jednak rozciągnięte na cały byt, natomiast u Böhmego pragnienie Ungrundu jest nieokreślone tylko w pierwszej fazie kształtowania się Boga. Należy dodać, że „formowanie” się Trójcy Świętej wyróżniane jest na poziomie logicznym, ponieważ czas, a wraz z nim świat widzialny, nie zostały jeszcze stworzone.

${ }^{23} \mathrm{~J}$. Böhme, Clavis Oder Schlüssel etlicher vornehmen Puncten und Wörter / so in allen des Authoris Büchern zufinden / deutlicher erkläret, Amsterdam 1682, \$ 13, cyt. za: J. Piórczyński, dz. cyt., s. 132.
} 
bezruchu. A jeśli wszystko byłoby „tylko Jednym, Jedno nie byłoby sobie samemu jawne"24. Dlatego też zasada samoobjawiania jest zespolona z samopoznawaniem. Ta myśl legnie również u podstaw filozofii Hegla ${ }^{25}$, który nadał jej jeszcze bardziej zdynamizowany charakter: „Siła ducha jest tylko tak wielka jak jej uzewnętrznienie"26. Proces samoobjawienia się Boga Böhme opisuje za pomocą metody dialektycznej. Pomimo że pozbawiona jest teoretycznej głębi, to Hegel dostrzega wartość „barbarzyńskich” pojęć łużyckiego teozofa. Böhme w następujący sposób sformułował zasady swej dialektyki:

Czytelnik powinien wiedzieć, że wszystkie rzeczy, bez względu na to, czy są to rzeczy boskie, diabelskie, ziemskie, czy jakie tam jeszcze można wymienić, polegają na tak i nie. Jedno jako „tak” jest tylko (eitel) siłą i życiem: i jest to prawda Boga albo sam Bóg. Bez „nie” ten Bóg byłby w sobie samym niepoznawalny [...] „Nie” jest tym, co przeciwstawne (Gegenwurf), wobec „tak”, czyli prawdy [...]: żeby prawda była objawiona i była czymś, jest w niej pewne contrarium, jest w niej wieczna miłość - jako coś aktywnego, wrażliwego, chcącego - i to, co jest do kochania. A przecież nie można powiedzieć, że „tak” i „,nie” są od siebie nawzajem oddzielone i istnieją jedne obok drugiego jako dwie rzeczy, lecz są one tylko jedną rzeczą, ale same się rozdzielają na dwa początki i stanowią dwa centra, ponieważ każde w sobie samym działa i chce. - Bez tych obu [elementów], które przecież pozostają w ciągłym sporze, wszystkie rzeczy byłyby Niczym i pozostawały w bezruchu ${ }^{27}$.

W teozoficzno-filozoficznej refleksji Böhmego „nie” można określić jako zapowiedź heglowskiego pojęcia negatywności. Stanowi ono zasadę różnicującą byt, „zagęszczającą” go i kierującą rozczłonkowane elementy przeciwko sobie. Z kolei „tak” znosi powstałe opozycje, przywracając na powrót jedność. Autor Fenomenologii ducha odnajduje w słowniku Böhmego termin "męka” (Qual), który również stanowi odpowiednik zasady rozdzielającej. Ojciec „ma jednak w sobie różnicę za sprawą męki; tzn. męka jest właśnie świadomą siebie, odczuwaną negatywnością" ${ }^{28}$. Hegel tym samym wskazuje, że Bóg

\footnotetext{
${ }^{24}$ Tenże, Mysterium Magnum, Oder Erklärung über das Erste Buch Mosis / Von der Offenbahrung Göttlichen Worts durch die drey Principia Göttliches Wesens / auch vom Ursprung der Welt und der Schöpffung, Amsterdam 1682, rozdz. III, \$22, cyt. za: J. Piórczyński, dz. cyt., s. 134.

${ }^{25}$ J. Piórczyński, dz. cyt., s. 134.

${ }^{26}$ G. W. F. Hegel, Fenomenologia ducha, t. 1, przeł. A. Landman, Warszawa 1963, s. 17.

${ }^{27}$ J. Böhme, Betrachtung Göttlicher Offenbahrung: rozdz. 3, \$2-5; cyt. za: G. W. F. Hegel, Wykłady z historii filozofii, t. 3, s. 249-250.

${ }^{28}$ Tamże, s. 230-231.
} 
w koncepcji Böhmego jest u swych źródeł dynamiczny oraz niekompletny, przynajmniej na etapie Ojca. Stanowi zbiór wszystkich rzeczy, potencjalnie w nim obecnych, lecz nie może siebie poznać bez wyłonienia czegoś przeciwstawnego, co pozwoliłoby mu na zrealizowanie swej doskonałości. Tym samym Bóg w koncepcji Böhmego spełnia swą boskość dopiero w opozycji do Stworzenia (nie-boskości), ponieważ bez niego owa boskość nie istnieje $\mathrm{w}$ sensie realnym. Wielość $\mathrm{w}$ absolucie może być zachowana tylko, gdy immanentnie znajduje się w nim element negacji i jest to lekcja, którą Hegel wyciąga $\mathrm{z}$ lektur Böhmego. W tym dialektycznym opisie formowania się bytu XVII-wieczny teozof, choć używając języka obrazowego, filozoficznie nieprecyzyjnego, zapowiada racjonalistycznie ujętą myśl Hegla: „negatywność jest punktem zwrotnym w ruchu pojęcia. Jest ona prostym punktem negatywnego samoodnoszenia, najbardziej wewnętrznym źródłem wszelkiej działalności, wszelkiego własnego ruchu życia i ducha"29. Tym samym Absolut Böhmego, a później i Hegla, musi rozwijać się zgodnie z zasadą negatywności, pogrążyć się w walce przeciwieństw, by w finale uzyskać pełne samopoznanie.

\section{Pojęcie Świętej Trójcy u Böhmego i jej rozwinięcie w systemie Hegla}

Zgodnie z przyjętą zasadą negacji Böhme dąży do zniesienia opozycji w bycie, opierając się w tym celu na pojęciu Świętej Trójcy, która również znajdzie swoje istotne miejsce w filozofii Hegla. Odtwarzając koncepcję teozofa $\mathrm{z}$ Łużyc, można dostrzec uderzające podobieństwa w sposobie, $\mathrm{w}$ jaki niemiecki filozof zreinterpretował to pojęcie w obrębie własnego systemu. W Fenomenologii ducha nie bez powodu uznaje on chrześcijaństwo za religię absolutną, ponieważ w pojęciu Trójcy Świętej dostrzega mityczną reprezentację trzech momentów spekulatywnej filozofii. Pierwszy element Trójcy, Ojciec, odpowiada „idei absolutnej”30. Musi on rozpoznać siebie w czymś innym, a jest to możliwe jedynie w naturze, która koresponduje z Synem ${ }^{31}$ - abstrakcyjność pojęcia zostaje zniesiona przez moment partykularny. Duch Święty reprezentuje oczywiście Ducha Absolutnego. Jest nim ludzkość, która zdobyła samoświadomość i pojęła znaczenie natury i siebie jako ucieleśnionej Idei. Tym

\footnotetext{
29 Tenże, O dialektyce, [w:] Hegel, T. J. Kroński, Warszawa 1966, s. 148.

${ }^{30}$ Tenże, Encyklopedia nauk filozoficznych, przeł. Ś. F. Nowicki, Warszawa 1990, s. 238.

${ }^{31}$ Stwierdzenie, że Hegel utożsamia naturę z Synem byłoby nadmiernym uproszczeniem. Według niego Chrystus symbolizuje również zniesienie dychotomii pomiędzy Bogiem i człowiekiem, ponieważ Jezus jest jednocześnie jednym i drugim, zob. G. A. Magee, The Hegel Dictionary, New York 2010, s. 249.
} 
samym Trójca uzyskuje spełnienie dzięki Duchowi, świadomości ludzi o Idei. Za pośrednictwem Ducha Absolut powraca do siebie - skończoność zostaje pojednana z nieskończonością. Na podstawowym poziomie Trójca Święta w teozofii Böhmego ma podobne znaczenie jak w systemie Hegla, choć została objaśniona w odmienny sposób. Ojciec, jako „chwytająca” wola bezgruntu, jest „abstrakcyjną neutralnością" ${ }^{2}$, „ciemnością i światłem, miłością i gniewem, ogniem i światłem" ${ }^{\prime 3}$. Dlatego też pierwszy element Trójcy figuruje jako zbiornik, w którym znajduje się wola i całość przeciwstawnych sobie elementów. Na tym etapie jednak przysługuje im status potencjalności. W związku z tym figura Ojca u Böhmego odpowiada Ojcu w interpretacji Hegla stanowi absolutną nieokreśloność i domaga się samoobjawienia. W teozofii Böhmego proces rozdzielania przeciwieństw i urzeczywistniania woli Ojca zapoczątkowuje Syn ${ }^{34}$. Określany jest również jako męka (Qual), Słowo, Separator, „który czyni wolę wiecznego Jednego zróżnicowaną - zróżnicowanie (Schedlichkheit) w woli [jako to], z czego powstają siły i własności]" ${ }^{35}$. Innymi słowy, rolą Syna jest rozdzielanie przeciwieństw, które złączone są w Ojcu. Jednocześnie figurę Syna należy rozumieć jako coś już określonego, negację nieokreśloności reprezentowanej przez Ojca. W tym kontekście postać Syna ma dwuznaczny, wręcz schizofreniczny charakter. Böhme nazywa go również das Ichts, a co Światosław Nowicki tłumaczy jako „Ja-jako-nic-będące-czymś”. Ten neologizm oparty jest na grze słów: Ich - oznaczające "Ja” albo „ego" oraz Nichts, czyli nic. Według Hegla Syn u Böhmego jest świadomością i samowiedzą ${ }^{36}$. Na podstawowym poziomie znaczenie postaci Syna w twórczości łużyckiego mistyka również jest podobne w koncepcji Hegla, ponieważ reprezentuje partykularność będącą w opozycji do abstrakcyjności

${ }^{32}$ G. W. F. Hegel, Wykłady z historii filozofii, t. 3, s. 234.

${ }^{33}$ J. Böhme, Von wahrer Gellasenheit [w zbiorze pt. Christosophia, oder Weg zu Christo], 1621, rozdz. II, $₫ 9-10$.

${ }^{34}$ Pierwotnie rolę Syna odgrywa w koncepcji Böhmego Lucyfer, który był pierwszym Jednorodzonym. Szatan uznał jednak siebie jako coś dla siebie samego, uzyskał byt i „odpadł”, jak wyraża się Hegel, na jego miejsce zaś przybył Chrystus. Upadek Lucyfera w kształtowaniu się Trójcy symbolizuje oczywiście narodziny zła i zostaje ono wpisane w proces samoobjawienia Absolutu. Można argumentować, że Bóg nie stanowi bezpośredniej przyczyny powstania zła w świecie, ponieważ decyzja Lucyfera była oparta na wolnym wyborze. Niemniej zło musiało potencjalnie być obecne w Ojcu, ponieważ by mógł objawić siebie jako dobro, musiał również umożliwić zaistnienie zła, które następnie przezwycięża.

35 J. Böhme, Von wahrer Gellasenheit [w zbiorze pt. Christosophia, oder Weg zu Christo], 1621, rozdz. rozdz. III, \$ 4-5; cyt. za: G. W. F. Hegel, Wykłady z historii filozofii, t. 3, s. 245.

${ }^{36}$ G. W. F. Hegel, Wykłady z historii filozofii, t. 3, s. 243-244. 
Ojca. Z kolei Duch u Böhmego jednoczy dwa poprzednie elementy Trójcy. Działanie Ducha symbolizuje ruch od wewnątrz na zewnątrz, niejako poza Absolut, by objawiać boskie cuda. Efektem jego pracy jest stworzony świat, stanowiący ekspresję mocy Boga ${ }^{37}$. Zarówno w idealizmie Hegla, jak i teozofii Böhmego to za sprawą Ducha Świętego Absolut uzyskuje samopoznanie ${ }^{38}$. W koncepcji mistyka warunkiem samowiedzy Boga są działania człowieka, które przeobrażają zarówno jego samego, jak i świat. Tutaj tkwi istotna różnica w stosunku do filozofii Hegla, ponieważ Böhme nie utożsamia czynów z ludzką świadomością, która dla autora Fenomenologii ducha wiąże się z kontemplacją Idei. Teoretycznie jednak w koncepcji Böhmego świadomość człowieka można by wpisać w proces samopoznania Absolutu, jeśli uznać ją za warunek konieczny ludzkiej aktywności, która zmierza do przeobrażania bytu.

Siedemnastowieczny mistyk zakłada, że wszystkie byty mają trójdzielną strukturę: „Nie możesz wymienić żadnego miejsca na niebie i ziemi, gdzie nie odbywałyby się boskie narodziny. - Narodziny Trójcy Świętej odbywają się również w twoim sercu; rodzą się w twoim sercu wszystkie trzy osoby"39. Według popularnej interpretacji także w systemie Hegla wszystko można sprowadzić do trójdzielnego schematu, który składa się z tezy, antytezy i syntezy ${ }^{40}$. Część badaczy jednak sprzeciwia się temu poglądowi, twierdząc, że jest to jedna $\mathrm{z}$ efektownych acz fałszywych etykietek, którą przypisano jego

${ }^{37}$ Wyraźny wpływ teozoficznego myślenia Böhmego można zauważyć w dwóch wczesnych tekstach Hegla z lat 1804-1805, w których używał słownictwa i stylu charakterystycznego dla twórczości mistyka z Łużyc, zob. J. Hoffemeister, Dokumente zu Hegels Entwicklung, Stuttgart 1936, s. 364-365. Drugi z tekstów został zniszczony, jednak zachował się jego opis, spisany przez biografa Hegla Karla Rosenkranza, zob. K. Rosenkranz, Hegels ursprüngliches System 1798-1806, „Literarhistorisches Taschenbuch” 1844, nr 2, s. 157-164. Hegel później skrytykował oba pisma, uznając je za przejaw „intuicji barbarzyńców” (die Anschauungen der Barbarei), zob. G. A. Magee, dz. cyt., s. 234-236; H. Schneider, Anfänge der Systementwicklung Hegels in Jena, „Hegel-Studien” 1975, nr 10, s. 133-171.

${ }^{38}$ Mogłoby się wydawać, że tym, co różni rozumienie Ducha przez Hegla i Böhmego jest fakt, że ten pierwszy identyfikuje do pewnego stopnia naturę z Synem, natomiast XVII-wieczny teozof wiąże efekt działania Ducha z całym światem stworzonym, włącznie z ludźmi. W Encyklopedii nauk filozoficznych można odnaleźć jednak fragment przeczący powyższemu zarzutowi, zob. dodatek do $\$ 246 \mathrm{w}$ : G. W. F. Hegel, Hegel's Philosophy of Nature: Being Part Two of the Encyclopedia of the Philosophical Sciences (1830), Translated from Nicolin and Pöggeler's Edition (1959), and from the Zusätze in Michelet's Text (1847), Clarendon Press 1970, s. 13.

${ }^{39}$ J. Böhme, Aurora oder Morgenröte im Aufgang 1612, rozdz. XI, $\$ 4$.

${ }^{40}$ Należy pamiętać, że Hegel nigdy nie posługiwał się tymi pojęciami. Zamiast nich używał: „abstrakt”, „negacja” i „konkret”. 
filozofii ${ }^{41}$. W zakończeniu Nauki logiki Hegel stwierdza, że to nie triadyczna struktura jest konieczna, lecz jej moment negatywny ${ }^{42}$. Podobieństwo między częstym występowaniem Trójcy w systemie Hegla i teozofii Böhmego nie jest przypadkowe. W latach 1804-1805 Hegel napisał tajemniczą pracę o Świętej Trójcy („divine triangle fragment”), która zdaniem Glenna Alexandra Magee jest dowodem na istotny wpływ teozofii Böhmego na wczesną twórczość Hegla $^{43}$. Pierwszy trójkąt, Bóg Ojciec, jest zamknięty w sobie i znajduje się w stanie wewnętrznego konfliktu zapowiadającego jego samoobjawienie. W Bogu Synu, reprezentującym drugi trójkąt, Bóg rozpoznaje siebie jako coś innego. Ten innobyt powinien zostać złączony z Bogiem, gdyż tkwi w nim potencjał czynienia zła. Hegel stwierdza, że Bóg Syn musi zejść na ziemię, pokonać zło i obudzić Boga do samopoznania. Trzeci trójkąt, Duch Święty, to Ziemia jako samoświadomość Boga, a także eteryczny Syn, w którym Bóg rozpoznaje siebie. W ten sposób święty trójkąt zostaje domknięty ${ }^{44}$. Na podstawie powyżej przytoczonego opisu można dostrzec zalążki późniejszego systemu Hegla. Bóg Ojciec odpowiada jego logice, a Syn filozofii przyrody. Obecna jest również Idea ucieleśniona w naturze, która domaga się samopoznania. Trzeci element, Duch Święty, to ludzkość, jaka uzyskała świadomość Idei, pozwalając na jej dopełnienie. Jednocześnie nie trudno zauważyć uderzające podobieństwa $\mathrm{z}$ interpretacją Trójcy dokonaną wcześniej przez Böhmego ${ }^{45}$.

W Fenomenologii ducha Hegel głosi, że „Prawda jest całością. Całością zaś jest tylko taka istota, która dzięki swemu rozwojowi dochodzi do swego osta-

${ }^{41}$ G. A. Magee, The Hegel Dictionary, New York 2010, s. 248.

${ }^{42}$ G. W. F. Hegel, Encyklopedia nauk filozoficznych, s. 254.W Wykładach z filozofii religii można jednak odnaleźć fragment przemawiający za tym, że Hegel dostrzega we wszystkich bytach Trójcę: „W nowszych czasach - już w bardzo określonych formach myślowych - odnowiona została przez filozofię Kantowska troistość jako typ [rozumiany] w sposób zewnętrzny, poniekąd jako schemat. Dalszą sprawą jest to, że skoro wiemy, iż ta troistość jest czymś istotnym i stanowi naturę Boga, to nie można jej utrzymać po tamtej stronie, nie można traktować tej idei jako jakiegoś tamtego świata, lecz [należy uznać], iż celem poznania jest rozpoznanie [tej] prawdy również w tym, co szczegółowe; a z poznania tej prawdy wynika, że wszystko, co jest prawdą w tym, co szczegółowe, zawiera to określenie. Poznać znaczy znać coś w jego określoności, naturą tego czegoś jest zaś natura samej określoności - i została ona ukazana w idei. To, że ta idea jest prawdą w ogóle, że wszystkie określenia myślowe są tym ruchem określania, jest przedstawieniem logicznym i koniecznością," zob. G. W. F. Hegel, Wykłady filozofii religii, t. 2, przeł. Ś. F. Nowicki, Warszawa 2007, s. 254-255.

${ }^{43}$ G. A. Magee, Hegel's Reception of Jacob Boehme, [w:] An Introduction to Jacob Boehme. Four Centuries of Thought and Reception, red. A. Hessayon, S. Apetrei, New York 2014, s. 235-236.

${ }^{44}$ K. Rosenkranz, dz. cyt., s. 163.

${ }^{45}$ G. A. Magee, dz. cyt., s. 235. 
tecznego zakończenia"46. A ta istota może go osiągnąć tylko dzięki obecności elementu negatywnego. Hegel postrzega rozwój historii jako proces wiedziony przez działanie negatywności. Implikuje ona konflikt, destrukcję, ale i umożliwia w ten sposób ujawnianie się Ducha w dziejach. Dzięki temu Absolut zyskuje coraz to większą samoświadomość, ponieważ element zanegowany także zostaje przeobrażony w swoje przeciwieństwo (negacja negacji), stając się częścią całości, w której podział na podmiot i przedmiot zostaje już zniesiony. Hegel identyczną zasadę dostrzega w teozofii Böhmego:

Podstawową ideą jest u niego dążenie, żeby wszystko utrzymać w absolutnej jedności - absolutna boska jedność i połączenie wszystkich przeciwieństw w Bogu. Jego główną, ba, można powiedzieć jedyną myślą, która przewija się przez wszystko, jest w ogólności Święta Trójca - [Böhme chce] we wszystkim uchwycić boską trójjedyność, wszystkie rzeczy [traktuje] jako jej odsłonięcie i przedstawienie; tak więc trójjedyność jest ogólną zasadą, w której i poprzez którą wszystko istnieje, i to tak, że wszystkie rzeczy mają w sobie tylko tę trójjedyność, nie jako trójjedyność wyobrażenia, lecz jako coś realnego - [jest to] absolutna idea ${ }^{47}$.

Ostatnie badania wskazują, że pojęcie Trójcy Świętej pełni w systemie Hegla funkcję wykraczającą poza zwykłą alegorię. Na niej opiera się nie tylko doktryna religii chrześcijańskiej, ale stanowi także oś, „dookoła której obracają się dzieje powszechne. Do tego punktu doszedł bieg dziejów i od tego punktu rozpoczął swój dalszy pochód"48.

Tym samym na motywie koła opiera się zarówno system Hegla, jak i teozofia Böhmego, który stwierdza, że

Byt boskości znajduje się więc we wszystkich końcach i miejscach w głębi bezgruntu, podobny do koła albo do oka, gdzie początek zawsze ma w sobie koniec [...] Jest to bowiem oko skierowane w siebie samo, trochę jak obrazowa postać, którą zobaczył prorok Ezechiel (rozdział I), kiedy jego duch-wola został wprowadzony w Boga, tzn. kiedy jego duchowa postać z pomocą Ducha Boga została wprowadzona w mądrość Boga, gdzie dostąpił on widzenia - i tak to musi być ${ }^{49}$.

${ }^{46}$ G. W. F. Hegel, Fenomenologia ducha, przeł. S. F. Nowicki, Aletheia, Warszawa 2002, s. 23.

${ }^{47}$ Tenże, Wykłady z historii filozofii, t. 3, s. 228.

${ }^{48}$ Tenże, Wykłady z filozofii dziejów, t. 2, przeł. J. Grabowski, A. Landman, Warszawa 1958, s. 216.

${ }^{49}$ J. Böhme, Sześć punktów teozoficznych, przeł. Ś. F. Nowicki, PWN, Warszawa 2013, s. 26. 
Motyw błędnego koła jest chyba najbardziej charakterystyczny dla teorii obu myślicieli, tym bardziej, że idea Trójcy w interpretacji Hegla i Böhmego również jest na nim oparta ${ }^{50}$. Na istotne znaczenie Trójcy w systemie Hegla wskazuje też jego trójpodział nauk na logikę (Ojciec), filozofię natury (Syn) i filozofię ducha (Duch) w Encyklopedii nauk filozoficznych ${ }^{51}$. W ostatnich dekadach pojęcie to zyskało większą uwagę wśród badaczy. Niektórzy, jak Walter Jaeschke ${ }^{52}$ i Peter C. Hodgson ${ }^{53}$, podkreślali racjonalistyczny wymiar Trójcy w systemie Hegla, natomiast inni, na przykład Cyril O’Regan ${ }^{54}$, jej mistyczny charakter ${ }^{55}$.

\section{Böhme jako źródło inspiracji dla Hegla i propozycja dalszych badań}

Z upływem czasu pozytywny stosunek Hegla do Böhmego zaczął przeważać, jednak nie przerodził się w bezkrytyczną afirmację. Autor Fenomenologii ducha w charakterystyczny dla siebie sposób, pisząc z perspektywy własnego systemu, stwierdza, że

...rozszerzył on [Böhme - przyp. F. K.] treść religii [doprowadzając ją] dla siebie do poziomu ogólnej idei, sformułował w swoisty dla niej sposób najwyższe problemy rozumu i próbował na jej gruncie ująć ducha i przyrodę w ich bardziej określonych sferach i ukształtowaniach, biorąc za podstawę to, że duch człowieka i wszystkie rzeczy stworzone są na obraz i podobieństwo Boga, oczywiście nie żadnego innego jak trójjedynego, i że są one tym życiem tylko po to, aby utraciwszy swój pierwowzór ponownie się z nim zespolić. Z drugiej strony, na odwrót, zastosował on w sposób brutalny formy rzeczy naturalnych (jak siarka, saletra, itd., cierpkość, gorycz, itd.) do form duchowych i myślowych ${ }^{56}$.

${ }^{50}$ Więcej o motywie błędnego koła w teozofii Böhmego i idealizmie Hegla zob. J. Böhme, dz. cyt., s. LV-LVIII; G. A. Magee, dz. cyt., s. 241.

${ }^{51}$ P. Redding, Hegel's Philosophy of Religion, http://paulredding.net/pubs2009andearlier/Redding_Hegels-Philosophy-of-Religion.pdf - dostęp: 23.08.2015.

${ }_{52}$ W. Jaeschke, Die Vernunft in der Religion: Studien zur Grundlegung der Religionsphilosophie Hegels, Frommann-Holzboog 1986.

${ }^{53}$ C. P. Hodgson, Hegel and Christian Theology: A Reading of the Lectures on the Philosophy of Religion, Oxford University Press 2005.

${ }^{54}$ C. O’Regan, The Heterodox Hegel, SUNY Press 1994.

${ }^{55}$ Paolo Diego Bubbio podkreśla, że pojęcie Trójcy rozważane było jedynie w kontekście filozofii religii Hegla. W swoim artykule przedstawia implikacje, jakie płyną z tych analiz dla rozumienia jego idealizmu, zob. P. D. Bubbio, Hegel, The Trinity, and the 'I', „International Journal for Philosophy of Religion" 2014, nr 2, s. 129-150.

${ }^{56}$ G. W. F. Hegel, Encyklopedia nauk filozoficznych, s. 24-26. 
Hegel wymienia również dialektykę i koncepcję negatywności ${ }^{57}$ jako zdobycze, które filozofia zawdzięcza Böhmemu. Pomimo znacznych różnic przede wszystkim na poziomie metody opisu, a także stopnia złożoności, podobieństwa między podstawowymi założeniami w koncepcjach obu myślicieli są uderzające. Niemniej historyk filozofii stoi przed bardzo kłopotliwym problemem, chcąc rzetelnie ocenić potencjalny „wpływ” Böhmego na Hegla. Wynika to $\mathrm{z}$ faktu, że prace mistyka z Łużyc są napisane bardzo mętnym stylem i pozostają otwarte na wiele interpretacji. Dlatego skłaniałbym się do przyjęcia tezy, która głosiłaby, że Hegel, będąc zaznajomiony z pismami Böhmego, przejął podstawowe rozwiązania strukturalne obecne w jego koncepcji, jak metodę dialektyczną, dynamiczną wizję Absolutu i ideę samoobjawienia, znaczenie poszczególnych części Trójcy Świętej czy motyw błędnego koła. Należy jednak z całą mocą podkreślić, że powyższe idee znalazły swe twórcze rozwinięcie w systemie Hegla, który nadał im ściśle filozoficzny wymiar i wpisał w tradycję niemieckiego idealizmu. Wyniki badań Glenna Alexandra Magee $^{58}$, a także Davida Walsha ${ }^{59}$ również przemawiają za przyjęciem powyższej tezy. Obaj historycy odnajdują w pismach Hegla bardzo widoczny wpływ obrazowego słownictwa Böhmego oraz poetyki charakterystycznej dla mitów, którymi łużycki teozof posługiwał się w swoich dziełach. I chociaż Hegel potępił swoje pierwsze próby filozoficzne, to niewątpliwie styl pisania Böhmego odegrał istotną rolę $\mathrm{w}$ jego intelektualnym rozwoju. W moim przekonaniu porównawcza analiza lingwistyczna dzieł Hegla i Böhmego dodatkowo zawęziłaby problematykę dotyczącą związków między koncepcją łużyckiego teozofa i pisma miniemieckiego myśliciela ${ }^{60}$. Przeprowadzenie takich badań pozwoliłoby na odnalezienie śladów bezpośredniej inspiracji twórczością Böhmego u Hegla nie tylko z jego wczesnego okresu, ale również w dziełach przypadających na okres filozofii ducha.

${ }^{57}$ G. W. F. Hegel, Wykłady z historii filozofii, t. 3, s. 258-259.

${ }^{58}$ G. A. Magee, dz. cyt., s. 234-236.

${ }^{59}$ D. Walsh, dz. cyt., s. 15-46.

${ }^{60}$ Zob. przedmowy do polskich tłumaczeń dzieł Hegla. Światosław Nowicki umieszcza w nich fragmentaryczne analizy dotyczące tego zagadnienia. 


\section{Bibliografia}

Atala K., A Study of the Nature of Reality and Language in J. Boehme's Aurora and G. W. F. Hegel's "Vorlesungen ueber die Philosophie der Religion III" (dysertacja doktorska), Catholic University of America 1988.

Böhme J., Aurora oder Morgenröte im Aufgang 1612.

Böhme J., Betrachtung Göttlicher Offenbahrung, Amsterdam 1682.

Böhme J., Clavis Oder Schlüssel etlicher vornehmen Puncten und Wörter / so in allen des Authoris Büchern zufinden / deutlicher erkläret, Amsterdam 1682.

Böhme J., Mysterium Magnum, Oder Erklärung über das Erste Buch Mosis / Von der Offenbahrung Göttlichen Worts durch die drey Principia Göttliches Wesens / auch vom Ursprung der Welt und der Schöpffung, Amsterdam 1682.

Böhme J., Sześć punktów teozoficznych, przeł. S. F. Nowicki, PWN, Warszawa 2013.

Böhme J., Von wahrer Gellasenheit [w zbiorze pt. Christosophia, oder Weg zu Christo] 1621.

Bubbio D. P., Hegel, The Trinity, and the 'I', „International Journal for Philosophy of Religion" 2014, nr 2, s. 129-150.

Faivre A., Christian Theosophy, [w:] Dictionary of Gnosis \& Western Esotericism, red. W. Hanegraaff, Brill, Leiden 2006, s. 258-267.

Haldane E., Böhme and His Relation to Hegel, „Philosophical Review” 1897, nr 2, s. $146-161$.

Hegel G. W. F., Encyklopedia nauk filozoficznych, przeł. Ś. F. Nowicki, PWN, Warszawa 2013.

Hegel G. W. F., Fenomenologia ducha, t. 1, przeł. A. Landman, PWN, Warszawa 1963.

Hegel G. W. F., Fenomenologia ducha, przeł. Ś. F. Nowicki, Aletheia, Warszawa 2002.

Hegel G. W. F., Hegel's Philosophy of Nature: Being Part Two of the Encyclopedia of the Philosophical Sciences (1830), Translated from Nicolin and Pöggeler's Edition (1959), and from the Zusätze in Michelet's Text (1847), Clarendon Press 1970.

Hegel G. W. F., Nauka logiki, t. 1, przeł. A. Landman, PWN, Warszawa 2011.

Hegel G. W. F., Nauka logiki, t. 2, przeł. A. Landman, PWN, Warszawa 2011.

Hegel G. W. F., O dialektyce, [w:] Hegel, T. J. Kroński, Wiedza Powszechna, Warszawa 1966.

Hegel G. W. F., Vorlesungen über die Geschichte der Philosophie III, E. Moldenhauer, K. M. Michel, Frankfurt am Main 1986.

Hegel G. W. F., Wykłady filozofii religii, t. 2, przeł. Ś. F. Nowicki, PWN, Warszawa 2007.

Hegel G. W. F., Wykłady z filozofii dziejów, t. 2, przeł. J. Grabowski, A. Landman, PWN, Warszawa 1958.

Hegel G. W. F.,Wykłady z historii filozofii, przeł. Ś. F. Nowicki, t. 3, PWN, Warszawa 2013. 
Hodgson P. C., Hegel and Christian Theology: A Reading of the Lectures on the Philosophy of Religion, Oxford University Press 2005.

Hoffemeister J., red., Dokumente zu Hegels Entwicklung, Fromann, Stuttgart 1936.

Jaschke W., Die Vernunft in der Religion: Studien zur Grundlegung der Religionsphilosophie Hegels, Frommann-Holzboog 1986.

Magee G. A., Hegel's Reception of Jacob Boehme, [w:] An Introduction to Jacob Boehme. Four Centuries of Thought and Reception, red. A. Hessayon, S. Apetrei, New York 2014, s. 224-243.

Magee G. A., The Hegel Dictionary, New York 2010.

Mayer P., Jena Romanticism and Its Appropriation of Jacob Boehme, Montreal 1999.

McGrath S., Boehme, Hegel, Schelling, and the Hermetic Theology of Evil, „Philosophy \& Theology" 2006, nr 18, s. 257-286.

O’ Regan C., The Heterodox Hegel, SUNY Press 1994.

Piórczyński J., Absolut, człowiek, świat: studium myśli Jakuba Böhmego i jej źródeł, PWN, Warszawa 1991.

Redding P., Hegel's Philosophy of Religion, http://paulredding.net/pubs2009andearlier/Redding_Hegels-Philosophy-of-Religion.pdf - dostęp 23.08.2015.

Rosenkranz K., Hegels ursprüngliches System 1798-1806, „Literarhistorisches Taschenbuch" 1844, nr 2, s. 157-164.

Schneider H., Anfänge der Systementwicklung Hegels in Jena, „Hegel-Studien” 1975, nr 10, s. 133-171.

Schussler I., Boehme und Hegel, „Jahrbuch der Schleischen Friedrich Wilhelms Universität" 1965, nr 10, s. 45-58.

Walsh D., The Esoteric Origins of Modern Ideological Thought: Boehme and Hegel (dysertacjadoktorska), University of Virginia 1978.

Walsh D., The Historical Dialectic of Spirit: Jacob Boehme's Influence on Hegel, [w:] History and System: Hegel's Philosophy of History, red. R. L. Perkins, Albany, New York 1984, s. 15-46.

\begin{abstract}
The Problem of Influence of Jacob Boehme's Theosophy on Georg Wilhelm Friedrich Hegel's Idealistic System
\end{abstract}

Educated historians of philosophy reluctantly expose connections between Western esotericism and the mainstream modern philosophy Esotericism is usually associated with intellectual quackery, which leads many of its followers to heresy and exclusion from the Christian world. However, prominent representatives of the 
European philosophy sometimes drew their inspiration from esoteric knowledge, e.g. G. Bruno and Spinoza from kabbalah or F. W. J. Schelling from F. C. Oetinger's theosophy. G. W. F. Hegel was probably aware that the esoteric thought played an essential role in the establishing of the modern scientific method. Therefore, in his Lectures on the History of Philosophy he devoted a separate chapter to J. Boehme, who provided the basis for the modern dialectic in his theosophy. The author of this article makes a comparative analysis between the elected elements of Boehme's and Hegel's thought and exposes many structural similarities in their works. At the same time, the author suggests that Boehme's theory could have been an important source of inspiration for Hegel, especially in the early phase of his intellectual development.

Key words: theosophy, Hegel, Böhme, Western esotericism, dialectic, Holy Trinity, idealism, mysticism. 